\title{
ホルミシス化粧品から受ける放射線被ばく線量の評価
}

古田 悦子 $* 1$, 中原 弘道 $* 2$

(2008 年 7 月 24 日受理)

(2008 年 9 月 5 日再受理)

Dose Estimation of Radiation Exposure from Hormesis Cosmetics

Etsuko FURUTA ${ }^{* 1}$ and Hiromichi NAKAHARA*2

\begin{abstract}
Cosmetics claiming hormesis effects are available through Internet. Although the hormesis effect is explained in each product of cosmetics, there is no explanation about the radiation source. The existence of the progeny nuclides of Th and $U$ series (RI) was comfirmed by the $\gamma$-ray spectroscopy using a HPGe detector. The highest radioactivity densities were $68 \mathrm{~Bq} / \mathrm{g}$ of the Th-series included in the hormesis powder. Because the particles containing RI were of the size of $1-10$ micrometer by observing and analyzing SEM-EDX, there is a risk of inhaling the powder to the deep into the lungs. Furthermore, as about $1 \%$ RI was dissolved in water, the uptake of the RI to the body would be possible. The highest value of the evaluation of uniform radiation exposure to some organs by the continuous usage for 10 years was $5.5 \mathrm{mSv} / \mathrm{y}$ of the hormesis powder inhalation to the lung. Furthermore, the calculated quantity of the radioactivity of progeny of ${ }^{222} \mathrm{Rn}$ deposited in the body after continuous use of the hormesis cream every day for one year becomes $24 \mathrm{~Bq}$. The possibility of accumulation of the radioactivity in the body from the hormesis cosmetics cannot be denied. The addition of the radioisotope to cosmetics is prohibited in some EU countries by the regulation. It's proposed in this paper that the legitimacy of the addition of the radioisotope should be seriously re-examined.
\end{abstract}

KEY WORDS: Hormesis cosmetics, Radioactive consumer products, NORM, SEM-EDX, PM2.5, External exposure, Internal exposure, EURATOM, $a$-Ray, Regulation and justification.

\section{I 緒 \\ 論}

20 世紀始めの欧州では， ${ }^{226} \mathrm{Ra}$ が多くの日用品に添加 され使われた。放射性同位元素（以下 RI と記す。）を添 加した日用品は, 放射性コンシューマプロダクト（以下 RCP と記す。）と呼ばれている。現在でも時計に使われ

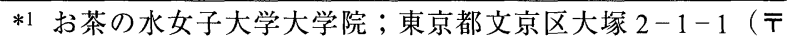
112-8610)

Ochanomizu University; 2-1-1 Ohtsuka, Bunkyo-ku, Tokyo 1128610, Japan.

*2 東京都立大学名誉教授 ; 東京都八王子市南大沢 1-1（禈 1920397)

Tokyo Metropolitan University; 1-1 Minami-Osawa, Hachioji, Tokyo 192-0397, Japan.
ている蛍光塗料やガスランタンマントル 1)が RCP とし て有名である。20世紀始めの RCP の中には，ウランを 添加したクリームやパウダーなどの化粧品が存在した。 しかし，欧州諸国では，1970年代の終わりまでにほぼ 全ての製造が中止された。 ${ }^{226} \mathrm{Ra}$ を添加した日用品は今 現在欧州連合の市場における流通はない。これらの日用 品は, あるとしても骨董品としての価值を認めた中古市 場にあるのみであり, 流通量は極めて少ないと考えられ ている2)。

最近では, 健康によいとする天然素材の手作り化粧品 が人気を博している。インターネットを通して日本語の ホームページ上において販売されている化粧品の一部 に，放射線ホルミシス効果 ${ }^{3}$ )を謳った商品（以下，ホル 
ミシス化粧品と記す。）がある。放射線ホルミシス効果 とは, 低線量放射線によって, 高線量で起こる障害とは 異なるプラスの刺激効果が生じることを指す。低線量放 射線生体影響の評価は各種研究機関において行われてき ている。しかしその殆どは，X線照射による小型動物あ るいは細胞レベルでの研究4)である。ホルミシス化粧品 の場合, RI を含むと考えられるが, RI の壊変によるホ ルミシス効果の研究は進んでいるとはいえない。

RCP は，法的な規制を受ける。例えば，欧州原子力

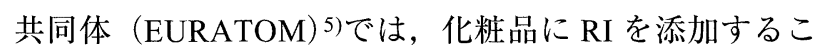
とを禁止している。ドイツなど欧州 6 か国がこれに従っ て法律により化粧品への RI の添加を禁止している。日 本の RCPへの対応としては, 放射線障害防止法の規制 下限值がある。さらに, RCP の内, 天然放射性同位元 素を添加した製品（Naturally Occurring Radioactive Material: NORM）は，核原料物質，核燃料物質及び原子 炉等の規制に関する法律施行令により, 添加可能な量と 濃度の上限值が定められている。しかし日本には，RCP の添加禁止対象品目は無い。

化粧品は, 医薬品と同様に人体に直接塗布する等の使 用方法であるため, 薬事法の規制を受ける。すなわち, 厚生労働大臣の製造販売業又は製造業の許可を受けた者 でなければ製造できず，また業としてこれらを輸入して はならないと定められている。これら化粧品の製造・輸 出入に関しては, 薬事法の理念に基づいた品質及び安全 性の確保に努めなければならない6)。化粧品の成分分析 法としての医薬部外品原料規格 2006 一般試験法7には 82 種の試験法が掲載されている。また，化粧品の安全 性確保のため, 化粧品には「添加禁止リスト」(ネガテ イブリスト）と「制限成分」（ポジティブリスト）があ る。ネガティブリスト等に含まれ元素等の有無がこれら 試験法により, 確認されている。しかし, このネガティ ブリスト・ポジティブリストの内容は，国などの規制当 局よって異なる。

日本では 2001 年に化粧品全成分表示制度が導入され, 成分の表示が義務付けられた。ネガティブリスト・ポジ ティブリスト以外の成分は, 企業責任の名の下に配合可 能となった。ホルミシス化粧品の放射化分析 ${ }^{8)}$ を行った が, その予備試験結果からはネガティブリストに揭載さ れた元素は存在しなかった。しかし, 一部の化粧品には, 表示されていない成分元素があることが明らかになっ た。さらに, 前記の化粧品の各試験法は RI を対象とし ていない。現在流通しているホルミシス化粧品の多くが, 放射線測定器に強く反応する。「ホルミシス」の説明が
ホームページ上にあり, 購入時には説明書が同封されて いるものもある。しかし, そこには放射線被ばく線量に 関する記載は無い。化粧品は, 購入後每日継続して直接 肌に塗布するものである。1950 年代に行われた脱毛症 等の治療を目的とした Thorium X $\left.{ }^{(224} \mathrm{Ra}\right)$ の人体皮虐へ の直接塗布 (化学形不記載) の結果, 皮䖉の癌化が検証 されている9）。しかも，塗布した ${ }^{224} \mathrm{Ra}$ (壊変核種と分 離した溶液に $\mathrm{CaCl}_{2}$ をキャリヤとして添加し, アルコー ル等を加え上薬としたもの）の $1 \%$ 前後が血液へ移行し ている10)ことが判明したため, この種の治療は中止さ れた。化粧品と治療目的の RI 濃度には, 相当な差があ ると考えられる。しかし, 化粧品としての継続的な RI の塗布による被ばく影響については, 報告がないので, 算出してみる必要がある。

ホルミシス化粧品の一つに, 粉体の「ホルミシス」粉 白粉が存在する。粉白粉は吸入の可能性もある。空気力 学径が $2.5 \mu \mathrm{m}$ 以下の微小粒子状物質 (Particulate Matter 2.5: PM2.5）の場合, 肺深部への吸入 - 沈着による健康 影響が公害問題として懸念されている11)。粉白粉に含 まれる RI の粒径が PM2.5 以下である場合, 肺深部での 内部被ばくの可能性があると考えられる。ホルミシス効 果の有無とは別に, これらホルミシス化粧品の使用によ る被ばく影響の検証が必要である。

本研究は, ホルミシス化粧品に含まれる放射性同位元 素の定性・定量分析を行い, さらに粒径確認によって体 内取り込みの可能性の検討を通し, 放射線源による内部, 外部被ばく線量評価を行った。

\section{II 実験}

\section{1. 試料と試料調整}

ホルミシス化粧品 6 種類, 対照試料 2 種類を試料とし た。ホルミシス化粰品は, 店頭販売されていない。イン ターネットを通して販売されている商品のうち, 会員に ならずに購入可能な全ての商品を選択した。ジェル2種 類, 石喃 2 種類, クリーム 1 種類, 粉白粉 1 種類であり, いずれも, 国産品である。また, 対照商品として, 一般 商品であってもミネラル成分が豊富な, すなわち天然放 射性同位元素の含有確率の高い化粧品の一つである国産 の泥パック, 及び韓国産のラドン温泉の元（バスパウダ 一）を選択した。

水溶性成分の移行率を求める簡易実験として, 各試料 約 $10 \mathrm{~g}$ に超純水（逆浸透膜を通した後, イオン交換樹 脂を通した高純度の水）約 $10 \mathrm{~mL}$ を加え軽く攪找後 $36.5^{\circ} \mathrm{C}, 24$ 時間インキュベーションした。この試料を密 
封状態で 1 週間静置し, 超遠心分離機を用いて水層, 油 層と沈殿層に分離した。

\section{2. 測定}

ホルミシス化粧品及び遠心分離後の各層の試料は $\mathrm{Ge}$ 検出器用容積標準線源 $\left({ }^{60} \mathrm{Co},{ }^{137} \mathrm{Cs}\right)$ と同一のプラスチ ック製 U8 容器に入れ, HPGe 検出器 (CANBERRA: GC3518）を用いて $\gamma$ 線を測定した。得られたスぺクト ルは, MCA (CANBERRA: Gemine-2000) と付属ソフト （CANBERRA: LabSOCS）を用いて解析した。装置の性 能は ${ }^{60} \mathrm{Co}$ の $\gamma$ 線 $1,333 \mathrm{keV}$ に対する相対効率 $35 \%$ ，工 ネルギー分解能 $1.8 \mathrm{keV}$ である。測定時間は, 試料の $\gamma$ 線強度に応じて $1 \sim 96$ 時間とした。 $\gamma$ 線解析により, 各試料中の各 RI の比放射能と水溶性成分の移行率を求 めた。

遠心分離した沈殿層は, 走查型電子顕微鏡（scanning electron microscopy: SEM）-エネルギー分散型 X 線分析 装置（energy dispersive X-ray spectroscopy: EDX）（Model JSM6700F）用の試料とした。試料をカーボンプレート 上で乾燥後, 加速電圧 $15 \mathrm{kV}$ により測定し, 粒径を確認 し含有元素を分析した。

\section{3. 被ばく線量評価}

（1）外部被ばく線量評価と評価条件

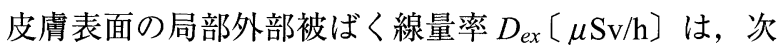
式を用いて算出した ${ }^{12)} 。$

$$
D_{e x}=\sum_{n} \Gamma_{E} \cdot A_{n} \cdot 10^{-6} \cdot d^{-2}
$$

ただし， $\Gamma_{E}$ は皮膚等価線量率定数 13)〔 $\mu \mathrm{Sv}$. $\left.\mathrm{m}^{2} / \mathrm{MBq} / \mathrm{h}\right] ， A_{n}$ は核種 $n$ の放射能〔 $[\mathrm{Bq}] ， d$ は試料と人 体皮膚表面の距離〔m]を表す。ここで用いた皮膚等価 線量率定数は, $\beta$ 線， $\gamma$ 線ともに $2 \pi$ 方向のみを対象と し，国際放射線防護委員会（ICRP）の Publication74 Table A 1414)に記載された皮膚吸収線量 $\mathrm{D}_{\mathrm{T}} / \mathrm{K}_{\mathrm{A}}$ （ $\mathrm{D}_{\mathrm{T}}$ ：臓 器の平均吸収線量, $\mathrm{K}_{\mathrm{A}}$ ：自由空気中の空気カーマ）の うち，前方から後方への照射ジオメトリー（AP）を使 用した。 $d$ は，国際放射線単位・測定委員会（ICRU） による皮膚等価線量評価深さである $70 \mu \mathrm{m}$ とした。使 用説明書に記載された化粧品の使用量を評価量とし，粉 白粉以外は日に 2 回使用することを想定した。1 日の使 用時間は，その目的に合わせて，ジェルとクリームは 23 時間，粉白粉は 12 時間，石畧は 5 分とした。

（2）内部被ばく線量評価と評価条件

ホルミシス化粧品の，ある日一日だけの使用及び 3,652 日までの継続的な使用に伴う体内残留量と排泄量 を，核種毎の残留関数および排泄率関数 15$)$ を用いて試
料別に算出した。Th 及び U 系列の核種は放射平衡に達 しているものとして計算した。また，アクチニウムの残 留関数は，女性の場合とした。

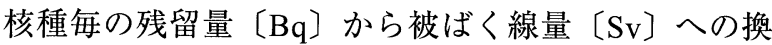
算は，簡易内部被ばく線量評価コード（Internal Dose Easy Calculation code: IDEC Ver.1.0)16)を用いた。IDEC による計算条件として，使用者は一般の女性，使用開始 年齢は 40 歳，連続使用（摂取）10 年とした。ただし， 放射能は 10 年間各化粧品を使用し続けた場合の総放射 能量〔Bq〕を一度に捸取したと仮定して，内部被ばく 線量を算出した。全ての化粧品の経皮摂取は，血液への 注入とみなした。ただし，血液への注入率は， $\gamma$ 線測定 から求めた水溶成分の $1 \%$ とした ${ }^{10)}$ 。経皮摂取後の全身， 骨表面, 肝臓, 腎臓, 全肺の内部被ばく線量を算出した。 粉白粉についてのみ, 吸入摂取も考慮し, 使用量の $0.1 \%$ にる全肺への内部被ばく線量を算出した。吸入 摂取時の呼吸気道から血液への移行は, 比較的不溶性の 遅い吸収速度である夕イプ $\mathrm{S}$ とたたエアロゾルとして の粒径は $2.5 \mu \mathrm{m}$ の対数正規分布とした。

化粧品の使用量，使用時間は，外部被ばく線量評価の 場合と同一とした。

\section{III 結果}

\section{1. 比放射能}

ホルミシス化粧品の $\mathrm{Ge}$ 検出器により測定した比放射 能と, 放射平衡が成立しているとして算出した系列毎の 試料別全比放射能を Table 1 に示す。試料 5 （石䄼）一 種類を除く全てのホルミシス化粧品に Th 系列, $\mathrm{U}$ 系列 の自然放射性同位元素が含まれていた。比較試料である 試料 8 （バスパウダー）と比べ, 全ての核種でホルミシ 又化粧品の比放射能は 1 桁から 2 桁高かった。最も比放 射能の高かった試料 6 (粉白粉) は， ${ }^{212} \mathrm{~Pb}$ 及び ${ }^{212} \mathrm{Bi}$ が $7.2 \mathrm{~Bq} / \mathrm{g}$ あった。このため， ${ }^{232} \mathrm{Th}$ 及び ${ }^{238} \mathrm{U}$ と放射平衡 にあるその子孫核種の比放射能の合計は，各々 68,13 $\mathrm{Bq} / \mathrm{g}$ と算出された。ホルミシス効果を謳っている試料 5 （石疅）および比較試料である試料 7 （一般化粧品）に は, 各 $\gamma$ 線エネルギー領域の自然計数（BG）の平方根 の 3 倍より大きい計数を示す放射性同位元素は存在しな かった（Table 1 では N.D.と記載した）。

2. 成分

SEM により測定した試料の画像とその拡大図を Fig. 1 に示す。Fig. 1 の拡大図中に記載した元素は, EDXを用 いたポイント解析による結果を表している。多数存在す る白く輝く粒子の粒径は，殆ど 1 から $10 \mu \mathrm{m}$ であり， 


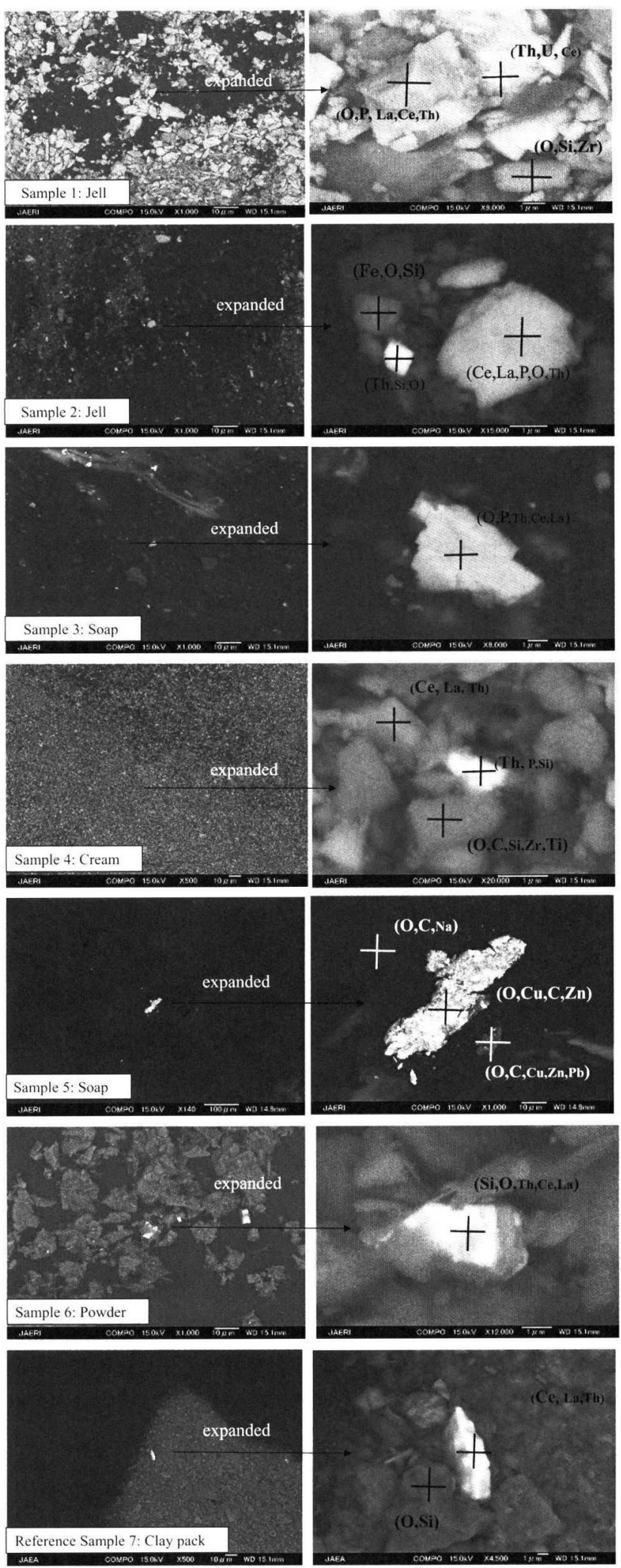

Fig. 1 Images of samples by SEM and elements detected by EDX.

The images on the left-sides and the expanded images on the right-sides were studied for each sample by SEM.

The elements written in the right-side images were analyzed for each grain by EDX.
$2.5 \mu \mathrm{m}$ 以下の粒子も多数存在した。Thおよび Uは，主 にこの粒子に含まれていた。他の黒や扊色粒子の Th 及 びUの含有率は低かった。白く輝く粒子であっても, 試料によりその成分比は違っていた。白く輝く粒子及び 灰色の粒子の EDX による解析結果例を Table 2 に示す。 試料 1 （ジェル）の白く輝く粒子は, $\mathrm{Th}(\mathrm{U})$ のリン酸塩 であった。一方，試料 6 (粉白粉) の白く輝く粒子は, Thのリン酸塩も含むが, $\mathrm{Ce}, \mathrm{La}$ の酸化物が多く含まれ ていた。Th(U)は, Ce, La(Y)の希土類元素とほとんどの 場合同時に存在した。白く輝く粒子以外の部分には, 試 料により差はあるものの, $\mathrm{Na}, \mathrm{Al}, \mathrm{Si}, \mathrm{K}, \mathrm{Ti}, \mathrm{Cr}, \mathrm{Fe}, \mathrm{Zn}, \mathrm{Zr}$, $\mathrm{Nd}, \mathrm{Yb}$ などが含まれていた。

\section{3. 外部被ばく線量}

比放射能から算出した，皮膚表面に打ける局部被ばく 線量值を Table 3 に示す。顔面を $300 \mathrm{~cm}^{2}$ とした単位面 積当たりの被ばく線量評価であり，周囲からの影響を評 価する積算は行っていないため，最小值を示している。 試料 4 (クリーム) の $2.9 \mathrm{mSv} / \mathrm{y}$ が最大值であった。化 粧品の使用説明書にある通りの使用量・時間であって も，一般公衆の皮䖉組織等価線量限度值である 50 $\mathrm{mSv} / \mathrm{y}$ を超す試料はなかった。

\section{4. 内部被ばく線量}

遠心分離した試料の水層, 油層, 沈殿層における放射 能を測定したところ沈殿部分が $90 \%$ を越す RI を含んで いた。一方, 水層は試料 1 （クリーム状のジェル）の $0.1 \%$ から試料 2 (水様のジェル) の $3.5 \%$ までの RI を 含んでいた。測定された $\gamma$ 線スペクトルは ${ }^{214} \mathrm{~Pb}$ 及び ${ }^{214} \mathrm{Bi}$ であり ${ }^{228} \mathrm{Ac} ，{ }^{212} \mathrm{~Pb}$ など $\mathrm{Th}$ 系列は検出されなかっ たことから，水層へ移行した成分はU 系列の ${ }^{226} \mathrm{Ra}$, ${ }^{222} \mathrm{Rn}$ と考えられた。

ホルミシス化粧品の使用に伴う体内残留量を Fig. 2 に 示す。実線が毎日連続使用した場合，点線が始めに1日 だけ使用した場合を示している。残留関数を用いた計算 によれば試料 4（クリーム）を 1 年使い続けた場合の体 内残留量は $24 \mathrm{~Bq}, 10$ 年では $64 \mathrm{~Bq}$ である。残留量は, 繰り返し使用することに伴い，初期は急速に，100日を 超えたころから僅かずつではあるが増加し続ける。一方， 排泄率関数を用いた計算による 1 年目の排泄量は 0.35 Bqであり，100日を超えたころから，排泄量はほぼ一 定となった。

IDEC を用いて算出した経皮摂取, 吸入摂取による内 部被ばく線量評俩值を Table 4 に示す。Th 系列の ${ }^{224} \mathrm{Ra}$, $\mathrm{U}$ 系列の ${ }^{226} \mathrm{Ra}$ 以下の核種の全てが放射平衡にあるとし て評㑋した。各化粧品を 10 年間使用し続けた場合の, 
Table 1 Radioactivity densities of hormesis cosmetics.

\begin{tabular}{|c|c|c|c|c|c|c|c|c|c|}
\hline \multirow{3}{*}{\multicolumn{2}{|c|}{ Sample }} & \multicolumn{8}{|c|}{ Radioactivity densities $(\mathrm{Bq} / \mathrm{g})$} \\
\hline & & \multicolumn{5}{|c|}{ Th series } & \multicolumn{3}{|c|}{ U series } \\
\hline & & ${ }^{228} \mathrm{Ac}$ & ${ }^{212} \mathrm{~Pb}$ & ${ }^{212} \mathrm{Bi}$ & ${ }^{208} \mathrm{Tl}$ & Total $^{* 1}$ & ${ }^{214} \mathrm{~Pb}$ & ${ }^{214} \mathrm{Bi}$ & Total $^{*}$ \\
\hline 1 & Jell & $4.3 \pm 0.12$ & $4.5 \pm 0.23$ & $4.5 \pm 0.16$ & $1.6 \pm 0.048$ & 44 & $1.1 \pm 0.048$ & $1.0 \pm 0.033$ & 15 \\
\hline 2 & Jell & \multicolumn{4}{|c|}{$(5.1 \pm 0.2) \times 10^{-2}(8.0 \pm 0.4) \times 10^{-2}(7.2 \pm 0.3) \times 10^{-2}(2.1 \pm 0.1) \times 10^{-2}$} & 0.7 & N.D. & N.D. & 0 \\
\hline 3 & Soap & $2.3 \pm 0.064$ & $2.3 \pm 0.11$ & $2.0 \pm 0.080$ & $0.86 \pm 0.025$ & 22 & $0.30 \pm 0.013$ & $0.22 \pm 0.0069$ & 3.6 \\
\hline 4 & Cream & $2.0 \pm 0.057$ & $2.2 \pm 0.11$ & $2.3 \pm 0.078$ & $0.76 \pm 0.023$ & 22 & $0.51 \pm 0.023$ & $0.50 \pm 0.025$ & 7.1 \\
\hline 5 & Soap & N.D. & N.D. & N.D. & N.D. & 0 & N.D. & N.D. & 0 \\
\hline 6 & Powder & $6.1 \pm 0.36$ & $7.2 \pm 0.41$ & $7.2 \pm 0.41$ & $2.6 \pm 0.16$ & 68 & $0.99 \pm 0.061$ & $0.85 \pm 0.099$ & 13 \\
\hline 7 & Clay-pack & N.D. & N.D. & N.D. & N.D. & 0 & N.D. & N.D. & 0 \\
\hline 8 & Rn-powder ${ }^{* 3}$ & $(3.4 \pm 0.1) \times 10$ & $5 \pm 0.2) \times 10$ & $1.5 \pm 0.2) \times 10$ & $6 \pm 0.2) \times 10^{-3}$ & 0.4 & $(3.0 \pm 0.1) \times 10^{-2}$ & $(1.0 \pm 0.03) \times 10^{-2}$ & 0.3 \\
\hline
\end{tabular}

The counts which were less than 3 times of the square root of BG'counts at the energy of the detective gamma ray were expressed as ND.

${ }^{208} \mathrm{Tl}: 36.0 \%$ from ${ }^{212} \mathrm{Bi}$

${ }^{*}$ : Total radioactive density is 10 times of average density of Th-series, when radioactive equilibrium is formed.

*2: Total radioactive density is 14 times of average density of U-series, when radioactive equilibrium is formed.

*3: Because the spectrum had a lot of small peaks and the counts of each nuclide above were very low, the BG counts at each nuclide were not estimated well and the ratios of nuclides were not obtained correctly. However the magnitude of the densities above is considered right.

Table 2 Examples of elemental composition ratio (percentages) ${ }^{*}$ contained in grains in centrifuged hormesis cosmetics.

\begin{tabular}{|c|c|c|c|c|c|c|c|c|c|}
\hline \multirow{2}{*}{\multicolumn{2}{|c|}{ Sample }} & \multicolumn{5}{|c|}{ White shinny grain } & \multicolumn{3}{|c|}{ Gray grain } \\
\hline & & Th & $\mathrm{U}$ & $\mathrm{Ce}$ & $\mathrm{La}$ & $\mathrm{Y}$ & Th & $\mathrm{Ce}$ & $\mathrm{La}$ \\
\hline 1 & Jell & $59.6 \pm 2.0$ & $29.9 \pm 1.2$ & $10.5 \pm 1.6$ & - & - & $19.1 \pm 4.1$ & $53.9 \pm 3.3$ & $27.0 \pm 3.0$ \\
\hline 2 & Jell & $76.6 \pm 4.1$ & - & - & - & $23.4 \pm 1.9$ & $27.4 \pm 5.0$ & $55.2 \pm 4.1$ & $17.4 \pm 3.8$ \\
\hline 3 & Soap & $25.8 \pm 7.8$ & - & $51.4 \pm 6.3$ & $22.8 \pm 5.8$ & - & - & - & - \\
\hline 4 & Cream & $89.0 \pm 1.4$ & - & $11.0 \pm 1.3$ & - & - & $4.6 \pm 4.1$ & $68.2 \pm 3.1$ & $27.2 \pm 2.8$ \\
\hline 6 & Powder & $26.1 \pm 0.7$ & - & $54.5 \pm 0.6$ & $19.4 \pm 0.6$ & - & $2.8 \pm 1.5$ & $70.3 \pm 1.2$ & $26.9 \pm 1.1$ \\
\hline 7 & Clay-pack & $11.4 \pm 6.3$ & - & $58.7 \pm 4.8$ & $29.9 \pm 4.4$ & - & - & - & - \\
\hline
\end{tabular}

There are no white shinny grain in samples 5 and 8 .

Sample 5 of silver gray grain contains $\mathrm{C} ; 62 \%, \mathrm{Cu} ; 19 \%, \mathrm{Zn} ; 12 \%$ and $\mathrm{O} ; 6 \%$.

Sample 7 of dark gray grain contains $\mathrm{O} ; 67 \%$ and Si; $33 \%$.

*: At each scan point, the elemental composition ratios were calculated multiplying each peak area by each elemental factor.

Table 3 Annual skin equivalent dose of hormesis cosmetics.

\begin{tabular}{ll|cc|cc}
\hline & Sample & $\begin{array}{c}\text { Usage weights } \\
\text { per day } \\
\end{array}$ & $(\mathrm{g})$ & $\begin{array}{c}\text { Usage hours } \\
\text { per day } \\
(\mathrm{h})\end{array}$ & \multicolumn{2}{|c}{\begin{tabular}{c}
$\gamma$ Annual dose \\
\cline { 5 - 6 }
\end{tabular}} & $\begin{array}{c}\gamma \text {-ray } \\
\left(\mathrm{mSv} / \mathrm{cm}^{2}\right)\end{array}$ & $\begin{array}{c}\beta \text {-ray } \\
\left(\mathrm{nSv} / \mathrm{cm}^{2}\right)\end{array}$ \\
\hline 1 & Jell: gray & $0.53 \times 2^{*}$ & $11.5 \times 2^{*}$ & 1.9 & 6.5 \\
\hline 2 & Jell: red & $0.32 \times 2^{*}$ & $11.5 \times 2^{*}$ & $1.5 \times 10^{-2}$ & $5.2 \times 10^{-2}$ \\
\hline 3 & Soap: red & $0.28 \times 2^{*}$ & $0.04 \times 2^{*}$ & $1.8 \times 10^{-3}$ & $5.9 \times 10^{-3}$ \\
\hline 4 & Cream & $1.6 \times 2^{*}$ & $11.5 \times 2^{*}$ & 2.9 & 9.5 \\
\hline 5 & Soap: green & $0.59 \times 2^{*}$ & $0.04 \times 2^{*}$ & $3.4 \times 10^{-8}$ & $4.2 \times 10^{-7}$ \\
\hline 6 & Powder & 0.16 & 12 & $5.0 \times 10^{-1}$ & 1.7 \\
\hline
\end{tabular}

The estimated area of a face is $300 \mathrm{~cm}^{2}$.

The evaluated distance is $70 \mu \mathrm{m}$.

${ }^{*}$ Two times per day with the same weight and hours. 


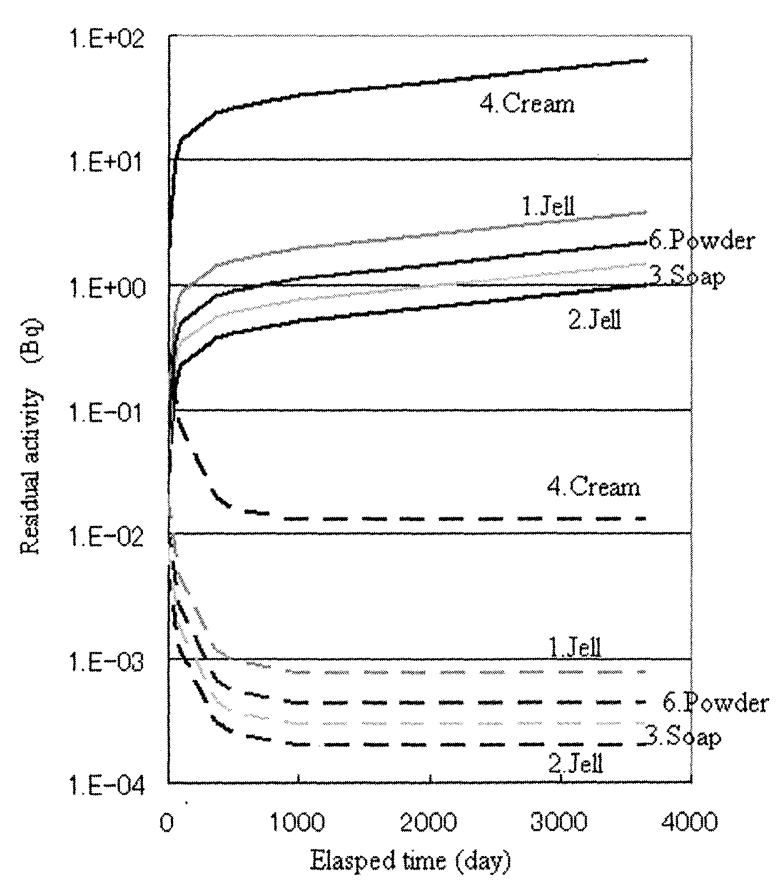

Fig. 2 Relationship between the residual activity and the elapsed time.

The solid lines show the residual activity in the user's body when cosmetics of each sample are used every day continuously.

The dotted lines show the residual activity in the user's body when cosmetics of each sample are used at the " 0 " day.

表中に示した各臓器に対する均一内部被ばく評価值を示 している。経皮摂取ではクリームの骨表面に対する 1.1 $\mathrm{mSv} / \mathrm{y}$ が最大值であった。一方, 試料 6 (粉白粉) の吸 入摂取による全肺の被ばく線量は $5.5 \mathrm{mSv} / \mathrm{y}$ であった。

\section{IV 考察}

\section{1. 比放射能}

ホルミシス化粧品は, 試料 5 (石畧) を除き全て天然 の放射性同位元素を含む NORM 製品であった。NORM 製品であるため核原料物質, 核然料物質及び原子炉等の 規制に関する法律の対象である。濃度規制值 $370 \mathrm{~Bq} / \mathrm{g}$ を越える化粧品は無かった。一方, NORM 製品は放射 線障害防止法の規制は受けないが，放射線障害防止法に 定められた ${ }^{228} \mathrm{Ra}$ と放射平衡にある核種の規制下限値 10 $\mathrm{Bq} / \mathrm{g}^{17)}$ を超えた化粧品が存在した。放射線障害防止法の 核種毎の規制下限值は, 安全基準であり, その值を大幅 に上回る放射性物質がホルミシス化粧品には添加されて いた。

\section{2. 被ばく線量評価}

内部被ばく線量の評価を行った。しかし, Table 4 に 示した評価值は参考值である。なぜならば, 評価条件と した使用量は，半分の人もいれば，倍量を使用する人も いる。使用者の年歯, 連続使用年数等もさまざまである。 さらに, 水への移行率を簡易実験により求めたが, 実際 には体温, 発汗, 皮脂分の浮き出しの度合い等で変動す るものと考えられ, 水溶成分の吸収の度合いも相当に個 人差があると考えられる。しかし，Fig. 2 に示したよう に, 計算上, 体内に取り达まれた $\alpha$ 線放出核種は, 排泄 もされるが残留分があり，体内残留量は徐々に増加する。

粒径が $2.5 \mu \mathrm{m}$ 以下（PM2.5）の Th(U)を含む微粒子が 存在することがSEMにより確認された。ホルミシス化 粧品は吸入により肺奥部への沈着が有り得ることが判明 した。Table 4 では全肺に対する内部被ばくを評価した。 試料 6 (粉白粉) からのホットパーティクルによる肺の 部分被ばく線量を $\alpha$ 線の飛程内の部分被ばくとして小出

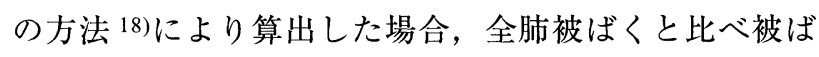
く線量評価值が 2 桁高くなる核種も存在した。このこと は, 直径 $50 \mu \mathrm{m}$ 前後の範囲に $0.1 \sim 1.2 \mathrm{mSv} / \mathrm{y}$ の被ばく が起こりえることを示している。

被ばく線量評価は, 種々の条件を勘案し安全側に過大 評価されるのが一般的である。しかし，ホットパーティ クルの存在を議論した例はほとんど見受けられない。実 際には, ホルミシス化粧品の粉白粉のように, 全肺への 議論では過小評価になる場合がある。今後, ホットパー ティクルの存在も考えた評価法が確立されることを望 む。

\section{3. 法規制と正当性}

外部被ばく線量の評価值等から, ホルミシス化粧品は 一般公衆に対する商品として, 違法性は無い。しかし, 普通の生活では起こりえない $a$ 線放出核種による内部被 ばくが起こる可能性がある。このことは, ホルミシス化 粧品の存在そのものが, 問題であることを示している。 さらに, EDXから, 欧州では化粧品への添加が禁止さ れている $\mathrm{Zr}$ の存在が確認された。日本においては, $\mathrm{Zr}$ はエアゾール剤への配合のみが禁止されている。これは 体内への吸入が危険であることを意味する。 $\mathrm{Zr}$ が存在 することに関しても, ホルミシス化粧品の存在は好まし くない。

一般的に, RCP の使用者にとって問題となる被ばく は, Rnの吸入を除き, 外部被ばくである。この被ばく 線量に関しては, RCP1 個につき $10 \mu \mathrm{Sv} / \mathrm{y}$ 以下が望まし いとする NRPB（現在の Health Protection Agency）の指 
Table 4 Uniform internal exosure of hormesis cosmetics in 10 years.

\begin{tabular}{|c|c|c|c|c|c|c|}
\hline Sample & $\begin{array}{c}\text { Usage } \\
\text { weights } \\
\text { (g/day) }\end{array}$ & $\begin{array}{l}\text { Percentage } \\
\text { dissolved } \\
\text { in water } \\
(\%)\end{array}$ & $\begin{array}{l}\text { Intake } \\
\text { method }\end{array}$ & $\begin{array}{c}\text { Total } \\
\text { activity in } \\
10 \text { years }{ }^{* 1} \\
(\mathrm{~Bq})\end{array}$ & Organs & $\begin{array}{c}\text { Radiation } \\
\text { exposure } \\
\text { dose } \\
(\mu \mathrm{Sv} / \mathrm{y})\end{array}$ \\
\hline \multirow[t]{5}{*}{$1 \quad$ Jell } & \multirow[t]{5}{*}{1.06} & \multirow[t]{5}{*}{$0.094^{* 2}$} & \multirow{5}{*}{$\begin{array}{l}\text { Intake } \\
\text { through } \\
\text { the skin }\end{array}$} & \multirow{5}{*}{3.8} & Whole body & 1.7 \\
\hline & & & & & Bone & 61 \\
\hline & & & & & Kidney & $6.0 \times 10^{-2}$ \\
\hline & & & & & Liver & 1.9 \\
\hline & & & & & Lung & $2.7 \times 10^{-1}$ \\
\hline \multirow{5}{*}{$2 \quad$ Jell } & \multirow[t]{5}{*}{0.64} & \multirow[t]{5}{*}{$3.4^{* 2}$} & \multirow{5}{*}{$\begin{array}{l}\text { Intake } \\
\text { through } \\
\text { the skin }\end{array}$} & \multirow{5}{*}{$9.9 \times 10^{-1}$} & Whole body & $3.7 \times 10^{-1}$ \\
\hline & & & & & Bone & 14 \\
\hline & & & & & Kidney & $2.0 \times 10^{-1}$ \\
\hline & & & & & Liver & $3.8 \times 10^{-1}$ \\
\hline & & & & & Lung & $7.0 \times 10^{-2}$ \\
\hline \multirow[t]{5}{*}{3 Soap } & \multirow[t]{5}{*}{0.56} & \multirow[t]{5}{*}{0.16} & \multirow{5}{*}{$\begin{array}{l}\text { Intake } \\
\text { through } \\
\text { the skin }\end{array}$} & \multirow{5}{*}{1.5} & Whole body & $6.1 \times 10^{-1}$ \\
\hline & & & & & Bone & 23 \\
\hline & & & & & Kidney & $2.7 \times 10^{-1}$ \\
\hline & & & & & Liver & $6.7 \times 10^{-1}$ \\
\hline & & & & & Lung & $1.0 \times 10^{-1}$ \\
\hline \multirow[t]{5}{*}{4 Cream } & \multirow[t]{5}{*}{3.2} & \multirow[t]{5}{*}{1.1} & \multirow{5}{*}{$\begin{array}{l}\text { Intake } \\
\text { through } \\
\text { the skin }\end{array}$} & \multirow{5}{*}{63.6} & Whole body & 29 \\
\hline & & & & & Bone & $1.1 \times 10^{3}$ \\
\hline & & & & & Kidney & 11 \\
\hline & & & & & Liver & 32 \\
\hline & & & & & Lung & 4.7 \\
\hline \multirow[t]{6}{*}{6 Powder } & \multirow[t]{6}{*}{0.16} & \multirow[t]{5}{*}{0.26} & \multirow{5}{*}{$\begin{array}{l}\text { Intake } \\
\text { through } \\
\text { the skin }\end{array}$} & \multirow{5}{*}{2.2} & Whole body & $9.1 \times 10^{-1}$ \\
\hline & & & & & Bone & 34 \\
\hline & & & & & Kidney & $4.0 \times 10^{-1}$ \\
\hline & & & & & Liver & 1.0 \\
\hline & & & & & Lung & $1.5 \times 10^{-1}$ \\
\hline & & $\begin{array}{l}\text { Inhalation } \\
\text { of } 0.1 \% \\
\text { used }\end{array}$ & Inhalation & 14 & Lung & $5.5 \times 10^{3}$ \\
\hline
\end{tabular}

\footnotetext{
${ }^{*} 1$ : The total activity intook is calculated by residual factor ${ }^{15)}$

${ }^{*}$ : Because the jell sample of number 1 is very creamy and the sample of number 2 is watery, so the percentages dissolved in water are different.
}

針 19)が在る。一方， RCP の使用者の内部被ばくの限度 值に関する指針はない。今回調べたホルミシス化粧品の ように内部被ばくの可能性のある RCP が存在するので, 一般公衆への内部被ばく限度值に関する指針が望まれ る。

欧州ではいかなる濃度, 量の RIであっても, 化粧品 以外にも, 食品, 玩具, 家畜飼料等への添加が禁止され ている。この禁止は, 科学的なデー夕の蓄積からいかな る量も危険であるといった結論を出しているのではな く, 添加の正当性が認められない対象品目を制定したも のである。一方, 日本では, RI は核種毎の濃度, 数量 により規制されており，添加禁止対象品目は無い。
NORM といえども，内部被ばく影響の大きい $\alpha$ 線源を 化粧品などに添加して良いか，正当性があるのか疑問で ある。放射線審議会において，NORMに係わる規制免 除レベルの国内規制体系への取入れの検討が行われてい るところである 20)。添加禁止対象品目の制定を真剣に 推し進めるべきであると考える。

\section{$\mathbf{V}$ と め}

本研究において用いたホルミシス化粧品はほとんど全 て，Th(U)を添加した NORM 製品であった。一般公衆の 皮虐表面の被ばく線量限度值を超える化粧品はないと評 価された。一方，その粒径及び使用形態から $a$ 線放出核 
種の部分的体内蓄積の可能性が高いことが示唆された。 NORM 製品について, 添加の正当性の議論と添加禁止 対象品目の設定, 及び一般公衆の内部被ばく限度值の制 定が望まれる。

本研究の SEM 写真撮影と EDX 分析に当たり, 日本 原子力研究開発機構, 環境・原子力微量分析研究グルー プの江坂文孝博士と福山裕康氏にご協力いただきまし た。さらに, 内部被ばく線量評価の算出に当たり, 日本 原子力研究開発機構, 大洗研究開発センター安全管理部 の齋藤圭氏にご協力をいただきました。深謝したしま す。

\section{参考 文 献}

1) E. Furuta , Y. Yoshizawa and T. Aburai; Comparisons between radioactive and non-radioactive gas lantern mantles, J. Radiol. Prot., 20, $423-431$ (2000).

2) J. Shaw, J. Dunderdale and R. A. Paynter; A Review of Consumer Products Containing Radioactive Substances in the European Union, Radiation Protection, 146, 14 (2007)

3) T. D. LuCKEY; Physiological benefits from low levels of ionizing radiation, Health Phys., 43, 771 - 789 (1982).

4) K. Sakai, Y. Hoshi, T. Nomura, T. Oda, T. Iwasaki, K. Funita, T. YAmada and T. TANOOKa; Suppression of carcinogenic processes in mice by chronic low dose rate gamma-irradiation, Int. J. Low Radiat., 1, 142-146 (2003).

5) EU; Council Directive 96/29/EURATOM, Official Journal of the European Community (L159) p. 7 (1996).

6）厚生労働省令第百七十九号；医薬品及び医薬部外品 の製造管理及び品質管理の基準に関する省令 (2004).

7）高橋守；ミニファイル，原材料の規格と分析法，ぶ んせき，2007(1), 29-30 (2007).

8) E. Furuta, H. Nakahara, Y. Hatsukawa, H. Matsue, and H. SAKANE; Neutron Activation Analysis of Trace Elements in Japanese Hormesis Cosmetics, $J$. Radioanalyt. Nucl. Chem., 278 (3), $553-557$ (2008).

9) R. Rajaratnam, P. Balasubramaniam and J. R. MARSDEN; Thorium X and skin cancer: still a problem in the 21 st century, Clin. Exp. Dermatol., 32, 125-126
(2006).

10) S. J. Wyard, M. A. Nightingale and I. G. Austin; Radiation hazards in the use of thorium $\mathrm{X}$ for skin therapy, Br. J. Radiol., 28, 274-278 (1955).

11) 新田裕史 : 環境問題基礎知識, 国立環境研究所二工 ース, 20 (5), 8-9 (2001).

12) H. E. Knoche; Radioisotopic Methods for Biological and Medical Research, p. 340 (1991), Oxford University Press, New York.

13) 古田悦子, 森田裕子, 吉沢幸夫; 内装建材による内 部・外部被ばく線量評価, 保健物理, 42, 341-348 (2007).

14) ICRP; “Publication 74 ：外部放射線に対する放射線 防護に用いるための換算係数”，日本アイソトープ 協会訳, p194, p223 (1998), 日本アイソトープ協会, 東京.

15) 赤不準編集主查：内部被ばくにおける線量当量の測 定・評価マニュアル, p91-92 (1988), 原子力安全技 術センター，東京.

16) 日本原子力開発機構：簡易内部被ばく線量評価コー ド IDEC Ver.1.0 (2000).

17) International Basic Standards for Protection against Ionizing Radiation and for the Safety of Radiation Sources, IAEA Safety Series No.115, IAEA (1996).

$18)$ 小出裕章; 第 99 回原子力安全問題ゼミ, 原子力安 全研究グループ (2004).

19) NRPB-M836: Exemption levels for radioactive material added to consumer products 2, National Radiological Protection Board, Chilton Didcot UK (1997).

20) 放射線審議会第 10 回基本部会, 資料第 10-3号 (2003).

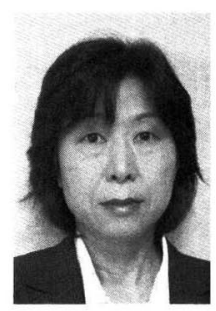

古田悦子（ふるた えつこ）

扮茶の水女子大学大学院講師。博士（理 学)。専門は放射化学。朝日新聞朝刊 (2008.8.5)の「私の視点」に掲載された, 放射性コンシューマプロダクトの正当性 の議論を深めていけたらと考えている。

E-mail: furuta.etsuko@ocha.ac.jp 